Should HIF-1a be incorporated in vitro to the CDCs and only thereafter the cells implanted in the myocardium, or should growth factors be applied straight to the myocardium? ${ }^{2}$ Neither revascularization alone of myocardial infarction nor administration only of additional viable allogeneic cells around the devitalized myocardial tissue may suffice for total functional myocardial recover. Cell transfer without paracrine effect is like revascularization without viable tissue.

\section{References}

1. Su T, Huang K, Mathews KG, Scharf VF, Hu S, Li Z, et al. Cardiac stromal cell patch integrated with engineered microvessels improves recovery from myocardial infarction in rats and pigs. ACS Biomater Sci Eng. 2020;6:6309-20.
2. Ostovaneh MR, Makkar RR, Ambale-Venkatesh B, Ascheim D, Chakravarty T, Henry TD, et al. Effect of cardiosphere-derived cells on segmental myocardial function after myocardial infarction: ALLSTAR randomized clinical trial. Open Heart. 2021;8:1-11.

3. Saha P, Kim MJ, Tulshyan A, Guo Y, Mishra R, Li E, et al. Hypoxia-inducible factor 1-alpha enhances the secretome to rejuvenate adult cardiosphere derived cells. J Thorac Cardiovasc Surg. 2023;165:e56-65.

4. Bonios M, Chang CY, Terrovitis J, Pinheiro A, Bartg A, Dong P, et al. Constitutive HIF-1a expression blunts the beneficial effects of cardiosphere-derived cell therapy in the heart by altering paracrine factor balance. J Cardiovasc Transl Res. 2011;4:363-72.

5. Tan SC, Gomes RSM, Yeoh KK, Perbellini F, Malandraki-Miller S, Ambrose L, et al. Preconditioning of cardiosphere-derived cells with hypoxia or propyl-4hydroxylase inhibitors increases stemness and decreases reliance on oxidative metabolism. Cell Transplant. 2016;25:35-53.

6. Wang F, Zhang G, Xing T, Lu Z, Li J, Peng C, et al. Renalase contributes to the renal protection of delayed ischaemic preconditioning via the regulation of hypoxia-inducible factor-1a. J Cell Mol Med. 2015;19:1400-9.

\title{
Commentary: The inconsistent field of cell-based therapy for postinfarct repair
}

\author{
Leora B. Balsam, MD
}

Saha and colleagues ${ }^{1}$ take another shot at cell-based therapy for postinfarct repair. Two decades since the earliest experimental work in this area appeared in the literature, it seems that many of the same pitfalls remain. Fundamentally, it is not known which cell type produces the most efficient and effective myocardial repair. Obvious challenges with cell-based therapy include achieving cell survival in the hostile environment of an infarct, delivering cells into the infarct zone without trauma, and determining the best time frame for cell therapy after infarction. Early in this

\footnotetext{
From the Division of Cardiac Surgery, UMass Memorial Medical Center, Worcester, Mass.

Disclosures: The author reported no conflicts of interest.

The Journal policy requires editors and reviewers to disclose conflicts of interest and to decline handling or reviewing manuscripts for which they may have a conflict of interest. The editors and reviewers of this article have no conflicts of interest.

Received for publication Aug 2, 2021; revisions received Aug 2, 2021; accepted for publication Aug 3, 2021; available ahead of print Aug 8, 2021.

Address for reprints: Leora B. Balsam, MD, Division of Cardiac Surgery, UMass Memorial Medical Center, University Campus, 55 Lake Ave N, Worcester, MA 01655 (E-mail: leora.balsam@umassmemorial.org).

J Thorac Cardiovasc Surg 2023;165:e67-8

$0022-5223 / \$ 36.00$

Copyright (c) 2021 by The American Association for Thoracic Surgery

https://doi.org/10.1016/j.jtcvs.2021.08.004
}

field, investigators reported that treatment with stem cells derived from adult tissues, including bone marrow, adipose tissue, and the heart, could achieve myocardial regeneration. This concept, which challenged the basic tenet that the adult heart was terminally differentiated, was largely refuted in later work. Currently, most in the field posit that the salutary effects of cell-based therapy are mediated by secretory products released in the infarct milieu (ie, a paracrine effect). 
Saha and colleagues ${ }^{1}$ use human adult cardiospherederived cells (CDCs) as their cell source in an acute rat myocardial infarction (MI) model. CDCs are a heterogeneous population of cells purified from cardiac tissue that can differentiate into multiple lineages, including cardiomyocytes, smooth muscle cells, and endothelial cells. The authors isolate adult CDCs from right atrial biopsies taken at the time of coronary artery bypass surgery and deliver these cells by local injection into the infarct border zone 10 minutes after ligation of the left anterior descending coronary artery in athymic rats. This population of cells has been studied previously in 2 randomized controlled clinical trials, both reporting equivocal results. In the Cardiosphere-Derived Autologous Stem Cells to Reverse Ventricular Dysfunction (CADUCEUS) trial, ${ }^{2,3}$ left ventricular (LV) scar size was reduced but global LV function was unchanged in patients treated with intracoronary autologous CDCs up to 3 months after MI, compared with control patients receiving standard care. In the Intracoronary Allogeneic Heart Stem Cells to Achieve Myocardial Regeneration (ALLSTAR) trial, ${ }^{4}$ no differences were seen in scar size or global LV function in patients treated with allogeneic CDCs versus placebo up to 1 year after MI. Unlike the design of CADUCEUS and ALLSTAR, Saha and colleagues ${ }^{1}$ deliver cells by local injection (rather than down the infarct-related coronary artery) and acutely at the time of MI. This design is less easy to translate to the clinical setting; however, it is reasonable to hypothesize that it may result in a different outcome than in CADUCEUS and ALLSTAR.

Saha and colleagues ${ }^{1}$ speculate that they can improve the potency of adult human CDCs for postinfarct repair by overexpressing hypoxia-inducible factor 1-alpha (HIF1 $\alpha$ ). This is an interesting hypothesis, given that Bonios and colleagues ${ }^{5}$ reported reduced potency of rat CDCs for postinfarct repair when HIF1 $\alpha$ was overexpressed. Saha and colleagues $^{1}$ achieve HIF- $1 \alpha$ overexpression through lentiviral transduction and find that the modified CDCs express higher levels of growth factors, including vascular endothelial growth factor-A, angiopoietin 1, stromal cell derived factor- $1 \alpha$, and fibroblast growth factor 2 in an in vitro model. When used for repair in the rat MI model, greater improvement in LV function is achieved with the HIF1 $\alpha$ overexpressing CDCs compared with CDCs transduced with empty vector.

Like many studies in the field of cell-based therapy, the report by Saha and colleagues ${ }^{1}$ adds some confusion because it is contrary to Bonios and colleagues ${ }^{5}$ previously published work. Although the authors believe this may be attributable to small differences in experimental design, their results highlight a challenge that limits the broader generalizability of cellbased therapy for postinfarct repair. When small differences in technique and design lead to very different results, the safety and efficacy of any therapeutic modality must be questioned.

\section{References}

1. Saha P, Kim M, Tulshyan A, Guo Y, Mishra R, Li D, et al. Hypoxia-inducible factor 1-alpha enhances the secretome to rejuvenate adult cardiosphere-derived cells. J Thorac Cardiovasc Surg. 2023;165:e56-65.

2. Makkar RR, Smith FF, Malliaras K, Thompson LE, Berman D, Czer LS, et al. Intracoronary cardiosphere-derived cells for heart regeneration after myocardial infarction (CADUCEUS): a prospective, randomized phase 1 trial. Lancet. 2012;379:895-904

3. Malliaras KM, Makkar RR, Smith RP, Cheng K, Wu E, Bonow RO, et al. Intracoronary cardiosphere-derived cells after myocardial infarction: evidence of therapeutic regeneration in the final 1-year results of the CADUCEUS trial (CArdiosphere-derived aUtologous stem cells to reverse ventricUlar dySfunction). J Am Col Cardiol. 2014;63:110-22.

4. Makkar RR, Kereiakes DJ, Aguirre F, Kowalchuk G, Chakravarty T, Malliaras K, et al. Intracoronary ALLogeneic heart Stem cells to achieve myocardial regeneration (ALLSTAR): a randomized, placebo-controlled, double-blinded trial. Eur Heart J. 2020;41:3451-8.

5. Bonios M, Change CY, Terrovitis J, Pinheiro A, Bath A, Dong P, et al. Constitutive HIF- $1 \alpha$ expression blunts the beneficial effects of cardiosphere-derived cell therapy in the heart by altering paracrine factor balance. J Cardiovasc Trans Res. 2011;4:363-72. 